\title{
COMPETITIVENESS OF SERBIA AND MACEDONIA AND THE ACCESSION TO THE EU IN A TIME OF CRISIS
}

\author{
Biljana Lazic ", Higher School of Professional Business Studies, Novi Sad \\ Jasmina Markov, Higher School of Professional Business Studies, Novi Sad
}

\begin{abstract}
The elapsed global economic and financial crisis has caused economic instability around the world and the consequences of crisis will be manifested in different forms for a long time. Destructive power of crisis has not bypassed developed countries that due to previous economic stability and financial strength managed to overcome the crisis waves quickly. However, for developing countries that are still economically unstable and financially very weak the crisis can indeed be fatal. The destruction of the domestic economy, the slowdown of economic trends, the decline in the standards of the population, the growth of external debt, constant inflation threats are just some of many effects of the crisis faced by Serbia and Macedonia. These republics of the former Yugoslavia in addition have shared history, similar institutional design and economic and political environment, and they have the same status in the EU accession process and similar levels of economic competitiveness. Following achieved levels of global and individual competitiveness of Serbia and Macedonia in the past five years, it will be explained how the crisis affected their key pillars of competitiveness, in which period the worst results were achieved and when the recovery and noticeable improvement began. Constant efforts to improve the competitiveness of these countries will provide faster and more efficient treatment of the effects of the crisis while intensifying their relations with the EU. The primary aim of this paper is to prove the existence of relations between the achieved level of competitiveness and the current EU status of analyzed countries while highlighting the fact that the enhancement of national competitiveness, fostering relations with the EU and the acceleration of the accession process also represent a primary weapon in the continuation of struggle with the consequences of the crisis.
\end{abstract}

Key words: crisis, competitiveness, European Union (EU), developing economies, SFR Yugoslavia

JEL classification: F15, F43, H12

\footnotetext{
*vps.biljalazic@gmail.com
} 


\section{KONKURENTNOST SRBIJE I MAKEDONIJE I PRISTUPANJE EVROPSKOJ UNIJI U VREMENU KRIZE}

Sažetak: Protekla globalna ekonomsko-finansijska kriza je izazvala privredne nestabilnsoti širom sveta, a njene posledice će se još dugo manifestovati u različitim oblicima. Uništavanje nacionalne privrede, usporavanje ekonomskih kretanja, pad standarda stanovništva, rast spoljnjeg duga i konstantne inflatorne pretnje su samo neki od mnogobrojnih efekata krize sa kojima se suočavaju Srbija i Makedonija. Ove bivše jugoslovenske republike vezuju zajedničke istorijske okolnosti, sličan institucionalni dizajn kao $i$ ekonomski $i$ politički ambijent, a takođe poseduju $i$ jednake statuse $u$ procesu pridruživanja Evropskoj uniji kao i slične dostignute nivoe privredne konkurentnosti. Prateći ostvarenu globalnu i pojedinačnu konkurentnost Srbije $i$ Makedonije u poslednjih pet godina, u radu će se objasniti kako je kriza uticala na ključne stubove njihove konkurentnosti, u kom periodu su ostvareni najlošiji rezultati kao i kada je otpočeo oporavak $i$ zabeležena primetna poboljšanja. Stalni napori na unapređenju konkurentnosti obezbediće brže $i$ efikasnije prevladavanje efekata krize $i$ intenziviranje odnosa sa Evropskom unijom. Osnovni cilj rada je dokazivanje postojanja povezanosti između dostignutog nivoa konkurentnosti i aktuelnog EU statusa analiziranih zemalja $i$ naglašavanje činjenice da unapređenje nacionalne konkurentnosti, održavanje $i$ negovanje odnosa sa Evropskom unijom $i$ ubrzanje procesa pristupanja predstavljaju primarno oružje u nastavku borbe sa posledicama krize.

Ključne reči: kriza, konkurentnost, Evropska unija, ekonomije u razvoju, SFR Jugoslavija

\section{INTRODUCTION}

The improvement of competitiveness of national economy has certainly been one of the main drivers of its economic recovery and future economic growth, and precisely, in this period of overcoming the consequences of the global crisis and expecting new instabilities on the European continent, it becomes highly desirable to analyze the competitive positions of Serbia and Macedonia as former Yugoslav republics. After the dissolution of the state union and the end of the war, they carried out various social, political and economic reforms in order to accelerate the process of accession to the EU. Two decades after the disappearance of SFR Yugoslavia from the global scene, each country has individually undergone an integration path towards the EU membership in accordance with their capacities. By fulfilling the defined obligations towards the Hague Tribunal as well as other necessary conditions, in March 2012 Serbia received candidate status for membership in the EU and now the current issue is determining the official date of commencement of the accession negotiations. "It is an extraordinary achievement and I hope that it will encourage Serbia to 
take further steps in order to meet the political and economic criteria for the membership in the EU, and I also hope that Belgrade will continue to support regional cooperation and good neighborly relations in the Western Balkans." (Rompuy, 2012). On the other hand, Macedonia can be proud of its rapid rise from the moment in 2004 when it had applied for membership in the EU, until the following year when it received candidate status. However, it is still unknown when it will start accession negotiations because of the main obstacle in the form of a protracted dispute between Greece and Macedonia regarding the name of this former Yugoslav republic.

Along with the realization of these processes of European integration, Serbia and Macedonia have been facing serious consequences of the global financial crisis. Huge contractions in consumer demand, sharp rise of unemployment, reduction of foreign investment, and decline in demand for export products are just some of the serious issues that need to be resolved as soon as possible. In very difficult economic and financial circumstances, it is of great importance for the above mentioned countries to consider their own economic situations realistically and to recognize their competitive position in order to act timely towards their improvement. In fact, one of the enormous consequences of globalization is such that competition is no longer viewed within national borders only (Jenkins et.al 1999). Through analyzing the publications of the World Economic Forum, including the Global Competitiveness Report, a certain national economy will become more capable of realizing the competitive advantages and disadvantages, improve its competitive position, create better conditions for stimulating its own economic growth and development and thus leave the vortex of global crisis as soon as possible and take more secure steps on the path towards the EU.

\section{CLOSENESS OF SERBIA AND MACEDONIA TO THE EU - THEN AND NOW}

One can freely say that the EU is one of the most developed and successfully implemented forms of economic and political integration in the world. It has passed a very long and arduous development path, made significant investments and undertaken numerous activities in order to gain its current position in the world (Marković \& Lazić, 2008). The Union has always attracted worldwide attention of officials, politicians, statesmen, scholars, students, but also the wider circle of people who are not otherwise engaged in this issue professionally. Today, in Serbia and Macedonia the question of joining the EU is becoming more and more prominent. The attitudes are numerous and very contradictory. Supporters of democratic values, free movement of people, capital, goods and services, certainly support the idea of joining the EU since it is seen as a very powerful and strong international integration. However, on the 
other hand, there are completely opposite attitudes of those expressing their disapproval and hostility towards the EU and its policies and thus find it completely unnecessary to become a member. This dismissive attitude is mostly based on ignorance, inadequate information or a complete lack of interest in this area. If we start to look for the answer to the question of whether a single nation can survive independently on the global stage, without cooperation with its neighbours primarily, and then with the other countries in the world, it will become clear that the EU is a need and necessity of the modern society.

The former Yugoslav socialist federation, known in the world as "Tito's Yugoslavia," was in economic terms far more developed than almost all of the socialist countries of the Soviet block. It was the leading country in the processes of formation and development of the Non-Aligned Movement countries along with India and Egypt. Emerging during the early sixties, the Non-Aligned Movement countries from Asia and Africa accelerated the historical process of abolishing the colonial reign (Pejanović, 2011). The basic objective of the activities of this movement was related to stopping the war conflicts in the world, resolving dangerous problems emerging due to block division of the world as well as preventing anti-peace processes. At the international level, Yugoslavia was stepping out as a nonaligned country, while the internal level included workers' self-government system in which the workers' council was the decision maker. Municipalities and towns in the Republic had the status of territorial communities that were managed by local self-government of their own people. Former system of exercising hegemonic and political goals sparked war conflicts in the nineties, the final decade of the last century in Croatia and Bosnia and Herzegovina, which also included Serbia and Montenegro that led to disastrous consequences for their population and economy.

The idea of European integration of the former economic and military force such as SFR Yugoslavia has completely disappeared, and after the final collapse of the community, each country (Slovenia, Croatia, Serbia, Montenegro, Macedonia and Bosnia and Herzegovina) crossed its integration path towards the EU individually. The countries that left the community peacefully, that is, Slovenia and Macedonia, were spared of the ravages of war and had more opportunities to join the processes of European integration and to independently move towards the EU. Other countries, exposed to war, had to go first through infrastructural, commercial and economic recovery, and then each of them individually commenced the negotiations with the EU regarding the candidacy for membership.

While researching the history of European integration in the former Yugoslavia, it can be concluded that the former "Tito's Yugoslavia“" had a very privileged treatment by, at that time, European communities which particularly 
distinguished it from the other countries of Central and Eastern Europe. The establishment of relations with the countries that were founders of the European Coal and Steel Community began back in the period prior to the commencement of European integrations. Later, the European Economic Community signed non-preferential trade agreements with Yugoslavia, whose significance was enormous, especially during the great block divisions in the world. The cooperation continued until 1991 when SFR Yugoslavia was institutionally and financially very connected with the European Communities and when it had a status that could have been considered even better than the status that would be granted to the future associated countries of Central and Eastern Europe. However, the conflicts on its territory began, followed by the imposition of sanctions by the European Community and the cancellation of the Cooperation Agreement among SFR Yugoslavia and EEC (Mišćević, 2007).

The advent of social and political circumstances that led to the breakup of former Yugoslavia and the independence of its countries started a new stage in the processes of European integration. Serbia and Macedonia, after the dissolution of the state union and the end of the war, carried out various political, economic and legal reforms in order to achieve a quicker accession to the EU. Among other things, they must respect human and minority rights, the liberal democracy, must establish stable institutions, the rule of law and stable market economy capable of facing the competition in the large European market (Stevović-Buha, 2007). Also, they must be able to take on all the obligations emerging from the membership, support the achievement of the goals of political, economic and monetary union.

Serbia and Macedonia, as well as some other Western Balkans countries, were identified as potential candidates for the EU membership during the Thessaloniki European Cuncil Summit in 2003. In 2008, a European partnership for Serbia was adopted, setting out priorities for the country's membership application and in 2009 it was formally applied. The process to ratify the Stabilisation and Association Agreement began in 2010, and in March 2012 Serbia was granted EU candidate status. Currently, Serbia is waiting for the European Council to decide on the date to start negotiations on its full membership.

Table 1

SERBIA - From potential candidate to a candidate country

01-06-2000 Feira European Council states all SAP countries are "potential candidates" for EU membership. 
01-06-2003 At the Thessaloniki European Council summit, the Stabilisation and Association Process (SAP) is confirmed as EU policy for the Western Balkans.

01-10-2004 Council conclusions open up a process for a Stabilisation and Association Agreement (SAA).

01-10-2005 Negotiations launched for SAA.

03-05-2006 SAA negotiations called off, because Serbia's co-operation with the International Criminal Tribunal for the former Yugoslavia has not improved.

13-06-2007 SAA negotiations resume, after Serbia commits to cooperating fully with the International Criminal Tribunal for the former Yugoslavia.

07-11-2007 SAA with Serbia is initialed.

01-01-2008 Agreements on visa facilitation and readmission enter into force.

18-02-2008 Council adopts revised European partnership for Serbia.

29-04-2008 SAA and Interim agreement on trade and trade-related issues are signed in Luxembourg.

19-12-2009 Visa requirement lifted for Serbs traveling to Schengen countries.

22-12-2009 Serbia applies for EU membership.

14-06-2010 EU members decide to start SAA ratification.

31-01-2011 Serbia replies to Commission questionnaire.

14-10-2011 European Commission delivers its Opinion on Serbia's EU membership application, granting candidate status based on one key priority.

01-03-2012 European Council confirms Serbia as a candidate country.

Note : Retrieved from http://ec.europa.eu/enlargement/countries/detailed-countryinformation/serbia/index en.htm

The former Yugoslav Republic of Macedonia applied for EU membership in March 2004. The commission issued a favorable opinion in November 2005, and the Council decided in December 2005 to grant Macedonia the status of candidate country. The Commission recomended that accession negotiations can be opened in October 2009. Macedonia was the first among the Western Balkans countries that signed the Stabilisation and Association Agreement (SAA) in April 2001 which entered into force in April 2004. 


\section{Table 2}

MACEDONIA - From potential candidate to a candidate country

01-01-1996 The former Yugoslav Republic of Macedonia becomes eligible for funding under the EC's PHARE programme.

01-01-1997 Council sets political and economic conditions for bilateral relations.

01-06-2000 Feira Summit states that all SAP countries are "potential candidates" for EU membership.

09-04-2001 Stabilisation and Association Agreement (SAA) is signed.

01-06-2001 Agreement on trade and trade-related matters enters into force.

22-03-2004 Application for EU membership.

01-04-2004 SAA enters into force.

17-05-2004 Council asks Commission to give opinion on application.

14-09-2004 1st meeting of Stabilisation and Association Council between EU and the former Yugoslav Republic of Macedonia.

14-02-2005 The country replies to EU questionnaire.

09-11-2005 Commission gives favorable opinion on the application of the former Yugoslav Republic of Macedonia for membership in the EU.

16-12-2005 Council grants candidate status to the country.

30-01-2006 Council adopts European Partnership.

01-01-2008 Visa facilitation and readmission agreements enter into force.

18-02-2008 Council adopts Accession Partnership for the former Yugoslav Republic of Macedonia, updating the 2006 European Partnership.

01-03-2008 Commission adopts Communication on the Western Balkans identifying benchmarks for next stage in accession process.

15-07-2009 Commission proposes to grant visa liberalisation to the country.

01-10-2009 Commission recommends opening of accession negotiations.

19-12-2009 Citizens of the former Yugoslav Republic of Macedonia, Montenegro and Serbia travel visa free to the Schengen area.

29-03-2012 European Commission launches a High Level Accession Dialogue with Skopje.

Note: Retrieved from http://ec.europa.eu/enlargement/countries/detailed-country-

information/fyrom/index_en.htm 
In future, Serbia and Macedonia have to make a huge effort in order to strengthen their institutional frameworks and carry out the necessary reforms. The EU certainly has a series of various instruments for the support and help to the mentioned states, and if an adequate communication and cooperation among the competent authorities of the Union and the representatives of Serbian and Macedonian authorities becomes established, the ultimate goal will become very realistic and achievable. The EU provides continuous support and financial assistance in order to help the country with the necessary reforms. For the period 2007-2013, assistance provided in the former Yugoslav Republic of Macedonia through IPA covers institution building, cross-border co-operation, regional development, human resource development and rural development.

\section{COMPETITIVENESS OF SERBIA AND MACEDONIA - TWO DECADES AFTER THE DISSOLUTION OF THE STATE}

The years to come, driven by a number of issues raised by the crisis, are likely to bring drastic changes in the global economy that will also affect the overall economic situation in many European countries. The territory of former Yugoslavia, with its turbulent history, controversial events and constant instability, has become an endless array of different topics for research and discussion. Also, a strategically good position, at the crossroads of global roads, increases the possibility of a more successful joint participation of these countries in the global market within contemporary conditions of extremely harsh global competition (Grandov, 2009). The Stabilisation and Association process for these countries, except Slovenia, was initiated by the EU in 1999. It is a political and institutional framework of a long-term EU policy towards these countries and it involves, among other things, the development of a political dialogue between the countries of the region with the use of conditionality policy that the Union uses to affect the countries of the region in order to maintain the reform processes and gradually approach the Union (Grandov, 2009). The mentioned conditionality policy promotes democracy and rule of law, respecting human and minority rights, conducting economic reforms and compliance with international obligations.

It is clear that Serbia and Macedonia have certain competitive advantages that in future may have impact on attracting foreign investors, promoting market economy, fostering economic growth and development and thus accelerating the process of overcoming the crisis and joining the EU. An analysis of the competitive position of these countries will confirm the above mentioned claims and demonstrate that, through improving their competitiveness, Serbia and Macedonia may in a stronger and easier manner resist the challenges of the crisis. With respect to the research methodology of the World Economic Forum, 
the initial step is to determine the belonging of the above mentioned countries to a certain stage of economic development.

First of all, it is necessary to take into account the realised value of gross domestic product per capita (GDP per capita) which is the most common and readily available measure of national welfare. It is used instead of the amount of wages in a particular country since this is neither internationally comparable nor easily obtainable. The World Economic Forum has designated the following reference values of GDP per capita that determines the belonging of a certain country to a certain stage of development.

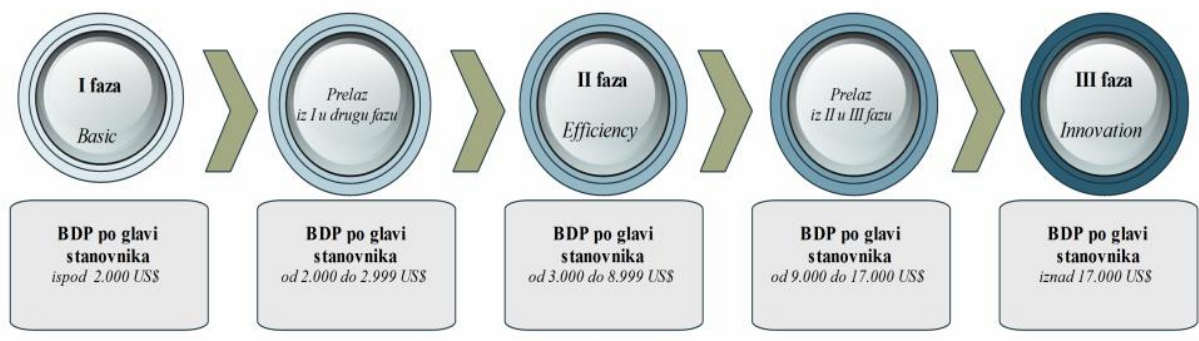

Figure 1. Values of GDP per capita in various stages of development of national economy. Retrieved from: The Global Competitiveness Report 2011-2012

According to the results of the World Economic Forum research, Serbia is in the second stage of economic development - efficiency driven stage (Ivanić, 2009). Since that stage involves economies that constantly generate the value of GDP per capita between 3000 US\$ and 8999 US\$, Macedonia is also there. The following figures present realised values of GDP per capita in the mentioned countries, in order to confirm the above mentioned statements.

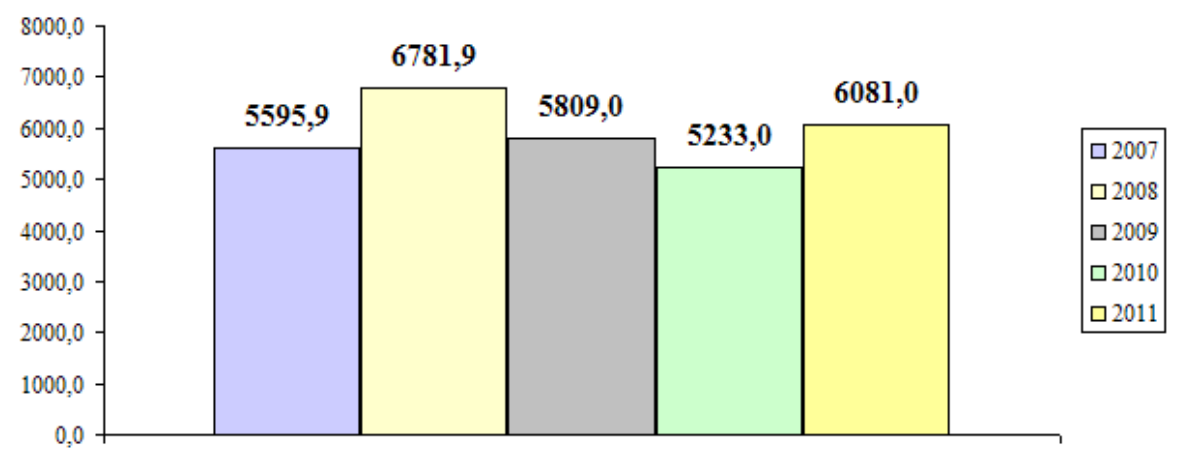

Figure 2. The value of GDP per capita in Serbia between 2007 and 2011. Retrieved from: Data extrapolation from The Global Competitiveness Report 2008-2009; 20092010; 2010-2011; 2011-2012; 2012-2013 


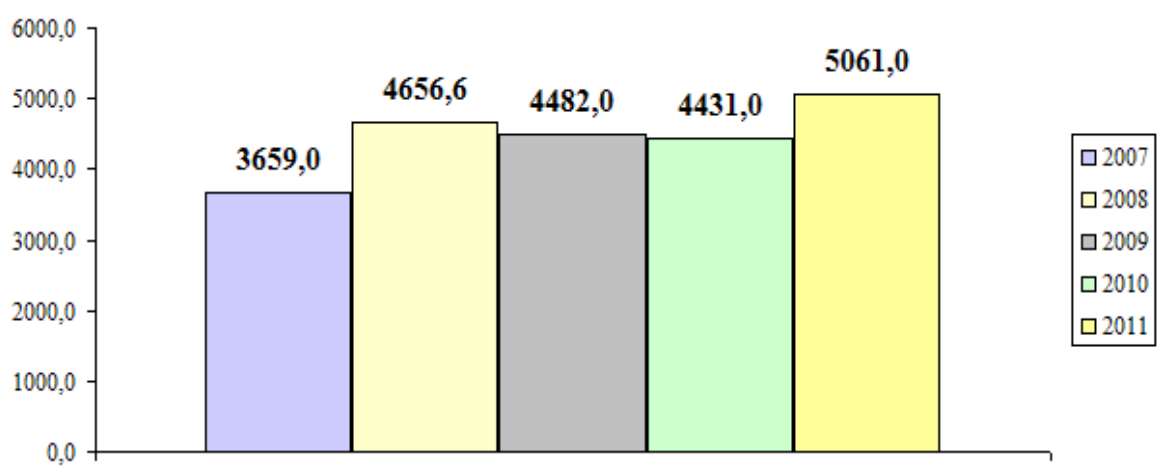

Figure 3. The value of GDP per capita in Macedonia between 2007 and 2011. Retrieved from: Data extrapolation from The Global Competitiveness Report 2008-2009; 20092010; 2010-2011; 2011-2012; 2012-2013

Notice that the value of GDP per capita declined in the period between 2008 and 2010 or persisted at approximately the same level. The year that was identified by the initial wave of the global economic and financial crisis is 2008 , which further explains the above mentioned movements. One of the key objectives of further development of Serbia is to increase the value of this indicator, i.e. to provide more welfare. To achieve this objective, Serbian economic development strategy must focus primarily on dynamic growth as the basic material condition of faster increase of the standard of living, reduction of unemployment and poverty (Bajec \& Jakopin, 2006). Like Serbia, Macedonia must constantly work on the increase of the value of GDP per capita in order to accelerate its own economic growth and development, improve its competitive position, move from its current second stage of development towards the following innovation-driven stage.

\section{THE NEED FOR IMPROVING COMPETITIVENESS AND STIMULATING FASTER RECOVERY FROM THE CRISIS}

Through mutual cooperation and support, Serbia and Macedonia have to work on improving competitiveness, raising the standard of living of their population, neutralising weaknesses and encouraging competitive advantages in order to reach better positions in the global competitiveness scale. High values of global index, individual subindices and pillars of competitiveness, as well as possession of many competitive advantages through constant efforts towards overcoming the disadvantages guarantee a more efficient exit from the crisis, and also speed up the process of European integration. 
Table 3

Actual values of Global Competitiveness Index and changes in position

\begin{tabular}{lllll}
\hline & \multicolumn{4}{c}{ Global Competitiveness Index } \\
\cline { 2 - 5 } Country & Position & Position & Position & Value \\
& $\mathbf{2 0 1 0 - 2 0 1 1}$ & $\mathbf{2 0 1 1 - 2 0 1 2}$ & $\mathbf{2 0 1 2 - 2 0 1 3}$ & $\mathbf{2 0 1 2 - 2 0 1 3}$ \\
\hline Macedonia & 79 & 79 & 80 & 4.0 \\
\hline Serbia & 96 & 95 & 95 & 3.9 \\
\hline
\end{tabular}

Note: Retrieved form The Global Competitiveness Report 2012-2013

Macedonia's current position is around the middle of the competitiveness list that, according to the current report, encompasses 144 countries of the world. Serbia is weakly positioned in the field of global competitiveness, and according to the current indicators it even lags behind all of the countries of the former Yugoslavia, but that does not necessarily indicate a similarly low position from the point of view of the individual subindices and pillars of competitiveness.

As it was previously explained, the realised value of GDP per capita is determined by the belonging of a certain country to a stage of economic development that is specified according to the methodology of the World Economic Forum. Serbia and Macedonia are in the second stage as they are characterized as efficiency-driven economies. Belonging to a particular developmental stage is very important in determining the percentage share of each subindex in the structure of global competitiveness index, and thus the degree of influence of the variables that make up the subindices onto the final result. The first subindex (Basic) refers to the fulfillment of basic conditions and its share in the structure of global competitiveness index in this case is $40 \%$.

Table 4

Actual values of the first competitiveness subindex

\begin{tabular}{lll}
\hline \multirow{2}{*}{ Country } & \multicolumn{2}{c}{ Basic Requirements } \\
\cline { 2 - 3 } & Position $(1-144)$ & Result $(1-7)$ \\
\hline Macedonia & 71 & 4.5 \\
\hline Serbia & 95 & 4.1 \\
\hline
\end{tabular}

Note: Retrieved from The Global Competitiveness Report 2012-2013 
As in previous years, Serbia lags behind Macedonia, because the underdeveloped institutional sector, critical condition of macroeconomic environment and very poor infrastructure capacities put it in the 95 th position. It must be noted in this case that Serbia has a very high quality primary education system, and very important scientific and research potential, which increase its competitiveness. These advantages make Serbia a particularly interesting investment destination for foreign investors.

The second subindex (Efficiency) discusses the incentives to efficiency which, in the case of both countries, represent the base of the complex phenomenon of competitiveness. It is this subindex that has the largest share in the structure of their global competitiveness indices and it goes up to $50 \%$.

Table 5

Actual values of the second competitiveness subindex

\begin{tabular}{lll}
\hline \multirow{2}{*}{ Country } & \multicolumn{2}{c}{ Efficiency Enhancers } \\
\cline { 2 - 3 } & Position $(\mathbf{1}-\mathbf{1 4 4})$ & Result $(\mathbf{1}-7)$ \\
\hline Macedonia & 84 & 3.8 \\
\hline Serbia & 88 & 3.8 \\
\hline
\end{tabular}

Note: Retrieved from The Global Competitiveness Report 2012-2013

Based on the presented results one can conclude how strong is the intensity of the advancement of the analysed countries in the area of higher education, how they work and whether they are sufficiently developed markets of goods and services, labour force and financial instruments. It also leads to information whether the analysed countries have reached the required level of technological equipment and development. All of the above indicators play a significant role in creating an attractive investment environment and attracting fresh foreign capital that will significantly affect the recovery of Serbian and Macedonian economy and encourage faster overcoming the world financial crisis' consequences.

The third subindex (Innovation) indicates the achieved level of competitiveness of a country from the aspect of its available resources and current attitude towards the development of innovations. It also discusses the development of the corporate culture and work ethic so that we can freely argue that only the developed countries in Europe can achieve good results in this field. Its share in the structure of global competitiveness index of Serbia and Macedonia is only $10 \%$. 


\section{Table 6}

Actual values of the third competitiveness subindex

\begin{tabular}{lll}
\hline \multirow{2}{*}{ Country } & \multicolumn{2}{c}{ Innovations } \\
\cline { 2 - 3 } & Position $(\mathbf{1}$ - 144) & Result $(\mathbf{1}-7)$ \\
\hline Macedonia & 110 & 3.1 \\
\hline Serbia & 124 & 3.0 \\
\hline
\end{tabular}

Note: Retrieved from The Global Competitiveness Report 2012-2013

Above all, the lack of financial resources in Serbia and Macedonia affected the neglection of the area of developing innovations and fostering corporate culture, which resulted in their lagging behind some of the countries of former Yugoslavia such as Slovenia and Croatia, and certainly behind many European countries. It is necessary for a number of years to pass in order to change the minds of people in the Western Balkans and their current attitude towards the importance of research, patenting, innovations and scientific development (Lazić \& Đorđević, 2009). In Serbia and Macedonia, there is still a lack of willingness to delegate authority among workers in companies and also a modest increase of participation of women in decision making structures. They certainly possess high quality scientific research institutions and expert scientific staff but seldom encourage cooperation between university institutions and industrial companies. These opportunities are often not exploited in the right way, which leads to missing many business opportunities and denial of chances for a more intensive economic development.

Each pillar, individually speaking, has a different level of importance and unequal influence in the formation of the competitiveness of a country mainly because of the obvious differences in the achieved levels of their economic development. Actual values and achieved positions of each pillars of competitiveness for Serbia and Macedonia are presented in Table No. 5. Underdeveloped institutional sector, modest infrastructural capabilities, inefficient commodity markets, a weak financial market and a very modest business culture are particularly problematic areas both in Serbia and Macedonia. Macedonia achieved a remarkable position in the field of macroeconomic stability, while for the others it can be said that the results are satisfactory considering the achieved level of economic development of the countries of this former Yugoslav republic as well as its political situation. The last three pillars of competitiveness are the main sources of weakness of Macedonia which, due to the modest size of the market, underdeveloped business culture and the lack of interest in the development and acceptance of innovation was not particularly attractive to foreign investors. In Macedonia, as 
in other Western Balkan countries, government often spends too much energy doing things they should not do. It distracts them from the things which would really be of their concern. The problem is not just that the government is too big, but it is not doing the right thing (Stiglitz, 2002).

Table 7

Acual values of pillars of competitiveness

\begin{tabular}{lllll}
\hline & \multirow{2}{*}{ Country } & \multicolumn{2}{c}{ Macedonia } & \multicolumn{2}{c}{ Serbia } \\
\cline { 2 - 5 } Pillars & $\begin{array}{l}\text { Position } \\
(\mathbf{1 - 1 4 4})\end{array}$ & $\begin{array}{l}\text { Result } \\
(\mathbf{1 - 7})\end{array}$ & $\begin{array}{l}\text { Position } \\
(\mathbf{1 - 1 4 4})\end{array}$ & $\begin{array}{l}\text { Result } \\
(\mathbf{1 - 7})\end{array}$ \\
\hline Institutions & $\mathbf{8 1}$ & 3.7 & $\mathbf{1 2 1}$ & 3.2 \\
\hline Infrastructure & $\mathbf{8 6}$ & 3.7 & $\mathbf{8 4}$ & 3.7 \\
\hline Macroeconomic environment & $\mathbf{3 7}$ & 5.3 & $\mathbf{9 1}$ & 4.5 \\
\hline Health and primary education & $\mathbf{8 0}$ & 5.5 & $\mathbf{5 2}$ & 5.8 \\
\hline Higher education and training & $\mathbf{8 0}$ & 4.0 & $\mathbf{8 1}$ & 4.0 \\
\hline Goods market efficiency & $\mathbf{6 3}$ & 4.3 & $\mathbf{1 3 2}$ & 3.5 \\
\hline Labor market efficiency & $\mathbf{7 2}$ & 4.3 & $\mathbf{1 1 2}$ & 3.9 \\
\hline Financial market development & $\mathbf{8 2}$ & 3.9 & $\mathbf{9 6}$ & 3.7 \\
\hline Technological readiness & $\mathbf{6 7}$ & 3.7 & $\mathbf{7 1}$ & 3.6 \\
\hline Market size & $\mathbf{1 0 7}$ & 2.8 & $\mathbf{7 0}$ & 3.6 \\
\hline Business sophistication & $\mathbf{1 0 5}$ & 3.5 & $\mathbf{1 3 0}$ & 3.1 \\
\hline Innovation & $\mathbf{1 0 5}$ & 2.8 & $\mathbf{9 7}$ & 2.9 \\
\hline
\end{tabular}

Note: Retrieved from The Global Competitiveness Report 2012-2013

Serbia is in a very bad position in the field of infrastructure, institutional development and macroeconomic stability and therefore it can be assigned to a group of underdeveloped and uncompetitive African countries. In recent years, Serbia has made significant progress in improving human health and extending life expectancy, as well as in the development of primary, secondary and higher education. The introduction of the Bologna principles in higher education has significantly innovated educational process and provided production of expert and qualified personnel with different profiles.

In both analysed countries there is a problem of illegal implementation of privatisation process which causes dissatisfaction and resentment of especially 
unemployed people but also those who, in difficult economic conditions, managed to keep their jobs. Perhaps the most serious problem with corruption is privatisation. The rhetoric of market fundamentalism argues that privatisation will reduce the activities to „rent-seeking“ from government officials, who „cream off" the profits of state enterprises or assign contracts and jobs to their friends. But, contrary to what was expected, privatisation made things much worse, so that it is in many countries jokingly called ,greasing“" (Stiglitz, 2002). The representatives of the EU in their declarations made during official visits to these countries often emphasize that corruption and illegal privatisation are very serious problems whose solution requires urgent implementation of efficient methods with the support of the authorities of the Union.

\section{CONCLUSION}

„Improving competitiveness, overcoming the crisis and encouraging Europeanisation of Serbia and Macedonia!"

After the dissolution of the state union and the establishment of stability in the region, Serbia and Macedonia started the processes of economic transformation and improvement of competitiveness that were unequal in intensity and therefore caused different dynamics of the process of approaching the EU. In continuation of the process of Europeanisation of social, economic, political and legal space of candidates for membership in the EU, much more than previous efforts must be made in order to improve their competitive position and thus accelerate overcoming the consequences of the crisis. This goal is very ambitious, and it takes a lot of time, resources and sacrifices in order to begin its implementation. One of the obstacles is the institutional sector in Serbia that is at a very low level of development, mainly due to the improper functioning of state structures, the presence of organized crime, anti-competitive conduct of economic entities and lack of interest in providing more favourable conditions for foreign investment. Constant threat of inflation, unfavourable interest rates and state budget deficits of Serbia and Macedonia are the current problems whose resolving is constantly postponed.

For Macedonia it can be said that it achieves quite consistent results from the pillars of competitiveness point of view, among which satisfactory macroeconomic environment stands out as a distinct advantage. There is a serious issue of the modest size of the domestic market, inadequate educational structure of the available labour force and very poor business culture and work ethic of the employees.

Despite the presence of numerous competitors' weaknesses and difficulties in the functioning of the national economy, Serbia should be praised for the rapid development of the Internet and telephone networks, which in the future may 
represent its significant competitive advantage and facilitate the conduct of business activities. In recent years there has been significant progress in the prevention of infectious and other diseases, protection of health and extending human life expectancy. If we add to the above mentioned the improvement of the systems of primary, secondary and higher education by introducing modern principles of work, we will notice that the competitive potential of Serbia certainly lies in capable, professional and skilled workforce. However, young professionals are seldom provided with adequate treatment after the completion of their education, which contributes to the phenomenon of "brain drain" from Serbia to continue into the future.

One of the key competitive weaknesses that makes both Serbia and Macedonia very unattractive for foreign investors is underdeveloped business culture, lack of professionalism in work and disregarding ethical values. In order to implement more effective and decisive struggle with the aftermath of the global crisis, in order to attain a higher level of economic development and to join the European family, Serbia and Macedonia must transform their economic and political systems as well as infrastructure frameworks and make enormous efforts to increase individual and global competitiveness.

\section{REFERENCES}

Bajec, J. \& Jakopin, E. (2006). Nacionalna strategija privrednog razvoja Srbije 2006-2012, osnovni nalazi, rezultati i rizici. Miločerski ekonomski forum „Evropski prioriteti i regionalna saradnja“, Savez ekonomista Srbije i Savez ekonomista Crne Gore

Dimitrijević, V. (1996). Evropska unija kao međunarodna organizacija. Zbornik radova "Pravo Evropske unije", Udruženje za pravo Evropske unije i Centar za međunarodne studije, JP Službeni glasnik, Beograd

Grandov, Z. (2009). Međunarodna ekonomija i globalizacija. Beograd: Beogradsko trgovačko društvo

Ivanić, V. (2009). Konkurentnost Srbije $i$ Vojvodine. Novi Sad: Centar za strateško ekonomska istraživanja Vojvodina-CESS

Jenkins, R., Barton, J., Bartzokas, A., Hesselberg J. and Knutsen M. H. (1999). Environmental regulation in the new global economy. UK: Edward Elgar Publishing

Lazić, B. \& Đorđević, M. (2009). Foreign direct investments and competitiveness enhancement of West Balkan countries. Proceedings from the Third International Conference „Regional cooperation and economic integration-challenges and opportunities", Ss. Cyril and 
Methodius University, Faculty of Economics Skopje and the Customs Administration of the Republic of Macedonia

Marković, S. \& Lazić, B. (2008). Evropska unija i njene institucije. Pravoteorija i praksa, Vol.25, Br.9-10

Miščević, T. (2007). Odnosi Srbije i EU - da li je moglo brže?. Zbornik radova konferencije „Evropska unija - prvih 50 godina”, Fakultet za ekonomiju, finansije i administraciju, Univerzitet Singidunum, Beograd

Pejanović, M. (2011). Zemlje Zapadnog Balkana i EU sa osvrtom na poziciju Bosne i Hercegovine u procesu integracije u EU, International Institute for Middle East and Balkan Studies, Ljubljana www.ifimes.org/print.cfm?jezik=Ba\&id=619

Stevović, Buha, J. (2007). Evropska unija i pridruživanje. Subotica: Ekonomski fakultet Subotica

Stiglitz, J. (2002). Protivrečnosti globalizacije. Beograd: SBM-x

Statement of the President of the European Council Herman van Rompuy, March 2nd, 2012.,

www.slobodnaevropa.org/content/srbija_dobila_status_kandidata_za_cla nstvo_u_eu/24501969.html

The Global Competitiveness Report 2012-2013., World Economic Forum, Geneva, 2001.,

www3.weforum.org/docs/WEF_GCR_Report_2011-12.pdf

The Global Competitiveness Report 2011-2012., World Economic Forum, Geneva, 2001., www3.weforum.org/docs/WEF_GCR_Report_2011-12.pdf

The Global Competitiveness Report 20010-2011., World Economic Forum, Geneva, 2010., www3.weforum.org/docs/WEF_GlobalCompetitivenessReport_201011.pdf

The Global Competitiveness Report 2009-2010., World Economic Forum, Geneva, 2009., http://www3.weforum.org/docs/WEF_GlobalCompetitivenessReport_200 9-10.pdf

The Global Competitiveness Report 2008-2009., World Economic Forum, Geneva, 2008.,

http://www3.weforum.org/docs/WEF_GlobalCompetitivenessReport_200 8-09.pdf 
91 COMPETITIVENESS OF SERBIA AND MACEDONIA AND THE ACCESSION TO THE EU IN A TIME OF CRISIS

http://ccmrbg.org/eubezbednost/?page=cource\&lang=srp\&subaction=showfull \&id $=1259670667 \&$ archive $=\&$ start_from $=\& u c a t=6 \&$.

European Commission Enlargement, http://ec.europa.eu/enlargement/countries/detailed-countryinformation/serbia/index en.htm.

European Commission Enlargement, http://ec.europa.eu/enlargement/countries/detailed-countryinformation/fyrom/index en.htm.

Primljeno: 30.01.2013. Odobreno: 01.03.2013. 